\title{
Trophic ecology and gill raker morphology of seven catostomid species in Iowa rivers
}

\author{
By J. R. Spiegel ${ }^{1}$, M. C. Quist ${ }^{2}$ and J. E. Morris ${ }^{1}$ \\ ${ }^{1}$ Department of Natural Resource Ecology and Management, Iowa State University, Ames, IA, USA; ${ }^{2}$ U.S. Geological Survey, \\ Idaho Cooperative Fish and Wildlife Research Unit, Department of Fish and Wildlife Resources, University of Idaho, Moscow, \\ ID, USA
}

\begin{abstract}
Summary
Understanding the trophic ecology of closely-related species is important for providing insight on inter-specific competition and resource partitioning. Although catostomids often dominate fish assemblages in lotic systems, little research has been conducted on their ecology. This study was developed to provide information on the trophic ecology of catostomids in several Iowa rivers. Food habits, diet overlap, and gill raker morphology were examined for highfin carpsucker Carpiodes velifer, quillback C.cyprinus, river carpsucker C. carpio, golden redhorse Moxostoma erythrurum, shorthead redhorse $M$. macrolepidotum, silver redhorse $M$. anisurum, and northern hogsucker Hypentelium nigricans sampled from four Iowa rivers (2009). Diet overlap among all species was calculated with Morista's index $(C)$. Food habit niche width was quantified with Levin's index $(B)$ and similarity in gill raker morphology was compared with analysis of covariance. Values from Morista's index suggested significant overlap in the diets of highfin carpsucker and river carpsucker $(C=0.81)$, quillback and river carpsucker $(C=0.66)$, and shorthead redhorse and silver redhorse $(C=0.67)$. Levin's index indicated that golden redhorse $(B=0.32)$, quillback $(B=0.53)$, and river carpsucker $(B=0.41)$ had the most generalized feeding strategies as their food niche widths were substantially wider than the other species. Gill raker length and spacing were positively correlated with the standard length of the fish for all species (gill raker length: $r^{2}=0.67-0.88, \mathrm{P} \leq 0.01$; gill raker spacing: $\left.r^{2}=0.63-0.73, \mathrm{P} \leq 0.01\right)$. Slopes of regression of gill raker length and spacing to standard lengths were significantly $(\mathrm{P} \leq 0.05)$ different among species, indicating that rates of change in gill raker morphology with body length varied among species. Differences in gill raker morphology likely allow catostomids to partition resources and reduce competitive interactions.
\end{abstract}

\section{Introduction}

The family Catostomidae consists of 76 species of fish that are widely distributed across North America (Cooke et al., 2005). Like many groups of fishes, catostomids are of high conservation concern in many regions due to their life history characteristics (e.g. movement patterns) and the widespread degradation of aquatic habitats (e.g. Cooke et al., 2005; Jelks et al., 2008). Of the 17 species native to Iowa, two species have been extirpated (i.e. lake chubsucker Erimyzon sucetta, greater redhorse Moxostoma valenciennesi) and five species (i.e. river redhorse $M$. carinatum, black redhorse $M$. duquesnei, silver redhorse M. anisurum, highfin carpsucker Carpiodes velifer, black buffalo Ictiobus niger) are either declining or their status is unknown (Zohrer, 2006).

Catostomids in Iowa are threatened by the same habitat alterations that have caused 68 of the 144 native fish species in Iowa to be identified as species of greatest conservation need (Zohrer, 2006). Since European settlement, the landscape of Iowa has undergone significant change whereby agriculture has altered over $80 \%$ of the land area (Natural Resources Conservation Service, 2000). Changes in land use from native prairie and forest to row crops and pasture have had substantial deleterious effects on lotic systems, including altered substrate composition (i.e. sedimentation), water quality (e.g. temperature, nutrient dynamics), and flow regimes (Morgan et al., 1983; Cooper, 1987; Holopainen and Huttunen, 1992; Litvan et al., 2007). Consequently, changes in watershed conditions and instream habitat have been associated with declines in fish assemblage diversity, reduced abundance and biomass, and shifts to assemblages dominated by trophic generalists (Karr et al., 1985; Walser and Bart, 1999). Many of the changes to the landscape occurred prior to the documentation of fish assemblages in Iowa, thus there is little historical data about native catostomid populations.

Traditionally, catostomids have received much less attention than prominent riverine sport fish species, such as smallmouth bass Micropterus dolomieui and channel catfish Ictalurus punctatus. However, catostomids and other non-game fishes (e.g. cyprinids, small-bodied percids and ictalurids) are an important component of aquatic food webs (Bertrand and Gido, 2007). The diversity of catostomids in Iowa is high with 17 species from seven genera (i.e. Cycleptus, Erimyzon, Ictiobus, Carpiodes, Moxostoma, Minytrema, and Hypentelium) native to the state's lakes, streams, and rivers (Zohrer, 2006). Many of these species have similar external morphology and often occur in sympatry. Thus, understanding how catostomids partition food resources may provide insight on inter-specific interactions, niche overlap, and food resource partitioning that allow for co-occurrence of species and may also provide insight with regard to conservation and management (McNeely, 1987; Gray et al., 1997). In addition to describing and comparing diets, knowledge of gill raker morphology may provide additional insight on the trophic ecology of fishes (e.g. Barton, 2007; Miller et al., 2007; Ingram and Shurin, 2009). Gill rakers are highly diverse with respect to their length, shape, and spacing, and their morphology typically reflects diet (Barton, 2007). For example, species with long rakers and small spacing typically feed on small invertebrate prey items whereas 
piscivores usually have short, stout, widely-spaced gill rakers (e.g. Ehlinger and Wilson, 1988; Barton, 2007; Wood, 2007).

In this study, we examined food habits and gill raker morphology of catostomids in Iowa rivers. The objectives of this study were to: (i) describe the food habits and gill raker morphology, (ii) evaluate trophic overlap, and (iii) evaluate how gill raker morphology might relate to partitioning of food resources of seven species of catostomids in Iowa rivers.

\section{Materials and methods}

River carpsucker C. carpio, highfin carpsucker, quillback $C$. cyprinus, shorthead redhorse $M$. macrolepidotum, golden redhorse M. erythrurum, silver redhorse, and northern hogsucker Hypentelium nigricans were sampled from four nonwadeable rivers in central and eastern Iowa during 2009. Sampled were the Boone, North Raccoon, Shellrock, and Wapsipinicon rivers. All four river systems are in the Mississippi River basin. The Boone and North Raccoon rivers are located in central Iowa and are tributaries to the Des Moines River. The Shellrock and Wapsipinicon rivers are located in eastern Iowa and are direct tributaries to the Mississippi River. A $3-\mathrm{km}$ reach was sampled from each river using boatmounted, pulsed-DC electrofishing (Smith Root VVP-15B, Vancouver, WA). Sampling sites were selected based on fish assemblage data collected in 2007 and 2008 by Iowa State University personnel (Neebling and Quist, 2010). Output was standardized to $3000 \mathrm{~W}$ based on water conductivity and dropper exposure (Burkhardt and Gutreuter, 1995). Each 3$\mathrm{km}$ reach was separated into six $500-\mathrm{m}$ sections to provide an estimate of variation for catch rates and to minimize stress to sampled fishes. Effort focused on channel habitats and was performed with a single pass in a downstream direction. All fish were collected by two netters. Although the species composition varied slightly among reaches, the seven catostomid species were relatively abundant across all reaches. The only exception was that river carpsucker was absent from the Wapsipinicon River.

Fish were processed at the end of each $500-\mathrm{m}$ section, identified, measured to the nearest $\mathrm{mm}$ for both total (TL) and standard length (SL), and weighed to the nearest gram. Fish were euthanized with a lethal dose of Finquel ${ }^{\mathrm{TM}}\left(200 \mathrm{mg} \mathrm{L}^{-1}\right.$; Argent Chemical Laboratories, Redmond, WA) and immediately processed in the field to minimize post-capture digestion. The digestive tract was removed from the esophagus by cutting at the junction of the esophagus and at the vent (Brezner, 1958). The entire digestive tract was fixed in $4 \%$ buffered formalin (Bowen, 1996). The gills including the pharyngeal pad were removed from the right side of the fish and similarly preserved. In the laboratory, gut contents were removed from the 'gizzard' to the first turn of the intestine (approximately the anterior $20 \%$ of the digestive tract) and placed in a petri dish for processing (Welker and Scarnecchia, 2003). A compound dissecting microscope was used to identify and count prey items which were identified to the lowest practical taxonomic level. Because many of the prey items were severely damaged from ingestion and digestion, the lowest taxonomic level was typically Order.

Several indices were used to quantify food habits. Frequency of occurrence $(\% \mathrm{~F})$ of each food category and invertebrate taxonomic order was estimated. In addition, the number of invertebrates consumed by each fish species was used to calculate prey specific abundance $(\% \mathrm{SA})$. Diet overlap between fish species was calculated using Morista's index.
Morista's index is a robust diet overlap index when prey numbers are available because it has the least bias for different resource distributions among species and varying sample size (Smith and Zaret, 1982). Morista's index was calculated as:

$$
C_{j k}=\frac{2 \sum_{i}^{n} P_{i j} P_{i k}}{\sum_{i}^{n} P_{i j}\left[\frac{n_{i j}-1}{N_{j}-1}\right]+\sum_{i}^{n} P_{i k}\left[\frac{n_{i k}-1}{N_{k}-1}\right]}
$$

where $C_{j, k}$ is Morista's index of diet overlap between species $j$ and $k, P_{i j}$ and $P_{i k}$ are the proportion of resource $i$ of the total resources used by species $j$ and $k$ respectively, $n_{i j}$ and $n_{i k}$ are the number of individuals of species $j$ and $k$ that use resource $i$, and $N_{j}$ and $N_{k}$ are the total number of each species in the sample. Index values $>0.60$ are generally considered to indicate significant overlap between two species (Zaret and Rand, 1971; Angradi and Griffith, 1990). In addition to Morista's index, prey importance, feeding strategy, and niche width were examined using a modification of the graphical Costello method (Amundsen et al., 1996). The Costello method plots prey-specific abundance against frequency of occurrence for assessment of fish diets at the population level (Chipps and Garvey, 2007). The location of prey items on the axis of the plot provides insight into feeding strategy (i.e. specialist or generalist), prey importance (i.e. high or low), and the contribution of prey items to niche width (Amundsen et al., 1996).

The diversity of food items consumed by catostomid species was further quantified by calculating Levins' index:

$B_{i}=\frac{\left(\frac{1}{\sum_{j} P_{i j}^{2}}-1\right)}{(n-1)}$

Where $B_{i}$ is Levins' index for species $i$, and $P_{i j}$ is the proportion of prey $j$ in predator $i$ 's diet, and $n$ is the number of prey categories (Marshall and Elliott, 1997). Index values vary from 0 to 1 with 0 representing species with specialized diets and 1 representing species with generalized diets. The first branchial arch from the right side of the body was removed to examine the length and spacing of gill rakers. The first branchial arch was selected because it typically contains the most well developed gill rakers (Nelson, 1967). Additionally, gill rakers located on other gill arches are generally smaller and contribute minimally to prey retention (O'Brien and Luecke, 1983).

Length and width of spacing between the inner edges of gill rakers was measured for five gill rakers centered on the angular gill arch (Tanaka et al., 2006). Gill raker length and spacing was measured to the nearest $0.001 \mathrm{~mm}$ using a microscope connected to a computer using image analysis software (IMAGE ProPlus 5.1; Media Cybernetics, Bethesda, MD). Differences in length and spacing of gill rakers among species were tested using analysis of covariance (ANCOVA), with standard length of each fish used as the covariate (Tanaka et al., 2006). Analysis of covariance was used to test if the slope of the regression of fish standard length to gill raker length or spacing was statistically different between two species. Prior to statistical analysis, measurements of gill raker length and spacing were averaged for each individual fish. Results from all statistical tests were considered significant at $\alpha=0.05$. All analyses were conducted using SAS (SAS Institute, 2008). 


\section{Results}

Stomachs were collected from 765 individuals, including 174 quillback, 123 highfin carpsucker, 135 river carpsucker, 107 golden redhorse, 124 shorthead redhorse, 60 northern hogsuckers, and 42 silver redhorse. Length varied within and among species (Table 1); mean lengths were typically lowest for northern hogsucker and highest for silver redhorse. Minimum and maximum total lengths were similar among species.

Diets of the study species varied among species, but were generally dominated by invertebrates associated with benthic habitats (Table 2). Interestingly, the presence of aquatic insects that are typically found in the water column or on the surface (e.g. chironomid larvae and subimagos, Ephemeroptera subimagos) in the stomach contents suggests that catostomids consume prey found throughout the water column. Although the study species could be considered generalists by the diversity of prey items in their diet, several species exhibited notable specializations. For instance, highfin carpsuckers consumed more mollusks than the other species $(\% \mathrm{~F}=23.7 ; \% \mathrm{SA}=55.4 ;$ Table 2$)$. Golden redhorse and northern hogsucker diets contained more Ephemeroptera (golden redhorse $\% \mathrm{~F}=77.5$; northern hogsucker $\% \mathrm{~F}=$ 66.0) and in higher numbers (golden redhorse $\% \mathrm{SA}=20.2$; northern hogsucker $\% \mathrm{SA}=40.8)$ than the other catostomid species (Table 2). Chironomid larvae were the most numerous prey item for golden redhorse, shorthead redhorse, silver redhorse, and northern hogsucker and the third most important prey item for highfin carpsucker, quillback, and river carpsucker (Table 2). Oligochaetes and mollusks were the most numerous prey items for highfin carpsucker, quillback, and river carpsucker. Algae were more common in the diet of
Carpiodes spp. than the other species (Table 2). Golden redhorse, quillback, and river carpsucker had the most generalized feeding strategies (Table 3) while highfin carpsucker, shorthead redhorse, silver redhorse, and northern hogsuckers had more specialized diets focused on a few prey items (Fig. 1).

Results from the diet overlap analysis indicated that only three species pairs overlapped significantly with regard to diet composition. Those pairs included highfin carpsucker and river carpsucker $(C=0.81)$, quillback and river carpsucker $(C=0.66)$, and shorthead redhorse and silver redhorse $(C=0.67$; Table 4). However, several other species pairs had moderate overlapping values between 0.40 and 0.60 , including golden redhorse and shorthead redhorse $(C=0.42)$, golden redhorse and silver redhorse $(C=0.44)$, highfin carpsucker and quillback $(C=0.52)$, northern hogsucker and shorthead redhorse $(C=0.45)$, northern hogsucker and silver redhorse $(C=0.48)$, and river carpsucker and shorthead redhorse $(C=0.42$; Table 4$)$.

Gill raker length and spacing was positively correlated with standard length for all species (length: $r^{2}=0.67-0.88$, $\mathrm{P} \leq 0.01$; spacing: $r^{2}=0.66-0.78, \mathrm{P} \leq 0.01$; Figs 2 and 3 ). Comparisons of the slopes of gill raker length to standard length were significantly different among species $(\mathrm{P}=0.0001)$, indicating that rates of change in gill raker length with standard length varied by species. Gill raker length increased fastest with changes in length for Carpiodes spp. Quillback, river carpsucker, silver redhorse, and highfin carpsucker typically had the longest gill rakers for a given standard length.

Similar to gill raker length, the slopes of gill raker spacing to standard length differed $(\mathrm{P}=0.0001)$ among species. Gill raker spacing increased with increasing standard length at a
Table 1

Mean, standard deviation (SD), minimum, and maximum length ( $\mathrm{mm}$ ) for seven catostomids sampled from four Iowa rivers, 2009

\begin{tabular}{llrrrrr}
\hline Common name & Scientific name & N & Mean & SD & Min & Max \\
\hline Highfin carpsucker & Carpiodes velifer & 123 & 312.4 & 34.8 & 220 & 423 \\
River carpsucker & Carpiodes carpio & 135 & 356.6 & 56.6 & 170 & 441 \\
Quillback & Carpiodes cyprinus & 174 & 349.7 & 71.5 & 187 & 480 \\
Northern hogsucker & Hypentelium nigricans & 60 & 290.3 & 71.5 & 182 & 465 \\
Golden redhorse & Moxostoma erythrurum & 107 & 344.8 & 59.1 & 194 & 432 \\
Shorthead redhorse & Moxostoma macrolepidotum & 124 & 307.5 & 58.3 & 170 & 460 \\
Silver redhorse & Moxostoma anisurum & 42 & 396.2 & 101.1 & 202 & 572 \\
\hline
\end{tabular}

Table 2

Frequency of occurrence $(\% \mathrm{~F})$ and prey specific abundance $(\% \mathrm{SA})$ of prey items in diets of catostomids sampled from four Iowa rivers, 2009. Species include highfin carpsucker (HFCS), quillback (QBCK), river carpsucker (RVCS), golden redhorse (GORH), shorthead redhorse (SHRH), silver redhorse (SVRH), and northern hogsucker (NHGS). Prey items include unidentified Diptera (D), Chironomidae larvae (Cl), Chironomidae pupae (Cp), Simulidae (S), Oligochaete (O), Bivalva (M), Pleocoptera (P), Ephmeroptera (E), Odonata (Od), Ceratopogonidae (Ce), Hemiptera $(\mathrm{He})$, Hirudinea $(\mathrm{Hi})$, Tricoptera $(\mathrm{T})$, Coleoptera $(\mathrm{Co})$, Planorbidae $(\mathrm{Pl})$, Cambaridae $(\mathrm{Cr})$, fish eggs, algae, and gravel

\begin{tabular}{|c|c|c|c|c|c|c|c|c|c|c|c|c|c|c|c|c|c|c|c|c|}
\hline Species & Index & $\mathrm{D}$ & $\mathrm{Cl}$ & $\mathrm{Cp}$ & $\mathrm{S}$ & $\mathrm{O}$ & M & $\mathrm{P}$ & $\mathrm{E}$ & $\mathrm{Od}$ & $\mathrm{Ce}$ & $\mathrm{He}$ & $\mathrm{Hi}$ & $\mathrm{T}$ & $\mathrm{Co}$ & $\mathrm{Pl}$ & $\mathrm{Cr}$ & Eggs & Algae & Gravel \\
\hline \multirow[t]{2}{*}{ HFCS } & $\mathrm{F}$ & 1.7 & 23.1 & 0.9 & 23.9 & 39.8 & 27.3 & - & - & - & - & - & - & - & - & - & - & - & 87.2 & 55.1 \\
\hline & SA & 2.3 & 8.3 & 0.8 & 0.8 & 39.8 & 23.7 & - & 1.7 & - & - & - & - & - & - & - & - & - & - & - \\
\hline \multirow{2}{*}{ QBCK } & $\mathrm{F}$ & 5.8 & 55.1 & 14.5 & 6.5 & 57.2 & 22.5 & - & 5.8 & - & - & - & - & - & - & - & - & - & 69.5 & 41.3 \\
\hline & SA & 4.2 & 23.1 & 25.2 & 0.6 & 26.4 & 19.7 & - & 0.6 & - & - & - & - & - & - & - & - & - & - & - \\
\hline \multirow{2}{*}{ RVCS } & $\mathrm{F}$ & 4.5 & 25.5 & 3.6 & - & 26.4 & 11.8 & 0.9 & 0.9 & - & - & - & - & - & - & - & - & - & 94.5 & 29.7 \\
\hline & SA & 1.6 & 28.2 & 1.0 & - & 31.0 & 33.4 & 1.8 & 2.9 & - & - & - & - & - & - & - & - & - & - & - \\
\hline \multirow[t]{2}{*}{ GORH } & $\mathrm{F}$ & 10.1 & 97.8 & 48.3 & 12.4 & 7.9 & 4.5 & 11.2 & 77.5 & 1.1 & - & - & 15.7 & 29.2 & - & 9.0 & 9.0 & 6.7 & 15.7 & 21.3 \\
\hline & SA & 17.4 & 26.3 & 6.7 & 0.8 & 1.4 & 1.3 & 0.6 & 20.2 & 0.1 & - & - & 4.3 & 4.2 & - & 9.2 & 0.5 & 6.9 & - & - \\
\hline \multirow[t]{2}{*}{ SHRH } & $\mathrm{F}$ & 10.4 & 93.8 & 41.7 & 15.6 & 26.0 & - & 11.5 & 26.0 & - & - & - & - & - & - & 18.8 & - & 10.4 & 6.3 & 11.5 \\
\hline & SA & 1.1 & 76.4 & 14.1 & 0.6 & 3.1 & - & 0.6 & 1.7 & - & - & - & - & - & - & 1.8 & - & 0.5 & - & - \\
\hline \multirow[t]{2}{*}{ SVRH } & $\mathrm{F}$ & 3.2 & 77.4 & 51.6 & 3.2 & - & 6.5 & 6.5 & 22.6 & - & 3.2 & 3.2 & 3.2 & 3.2 & 6.5 & - & - & 6.5 & - & - \\
\hline & SA & 0.2 & 58.5 & 16.7 & 0.2 & & 0.6 & 0.7 & 12.1 & & 0.6 & 0.2 & 0.2 & 0.2 & 0.7 & - & - & 9.2 & - & - \\
\hline \multirow{2}{*}{ NHGS } & $\mathrm{F}$ & 2.0 & 83.7 & 46.9 & 8.2 & & 2.0 & 4.1 & 66.0 & 2.0 & 4.1 & & 10.2 & 18.4 & 8.2 & - & - & 12.2 & 16.7 & 2.0 \\
\hline & SA & 0.2 & 41.8 & 4.2 & 1.5 & & 0.1 & 0.2 & 40.8 & 0.1 & 0.2 & & 1.7 & 2.0 & 0.5 & - & - & 6.7 & - & - \\
\hline
\end{tabular}



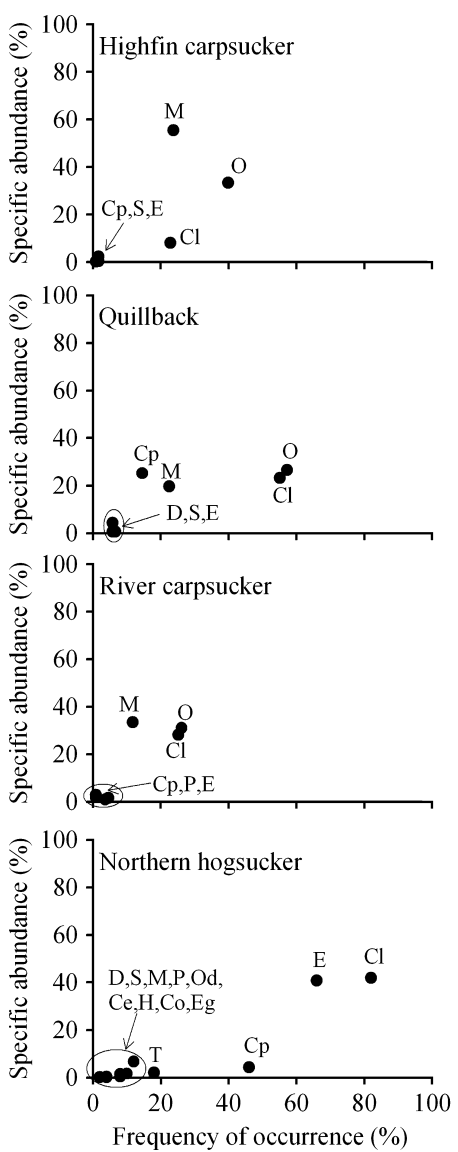

Fig. 1. Graphs of feeding strategy, prey importance, and niche width contribution of invertebrate categories for catostomids sampled from four Iowa rivers, 2009. Prey items include Diptera (D), Chironomidae larvae $(\mathrm{Cl})$, Chironomidae pupae $(\mathrm{Cp})$, Simulidae (S), Oligochaete $(\mathrm{O})$, Bivalva (M), Pleocoptera (P), Ephmeroptera (E), Odonata (Od), Ceratopogonidae (Ce), Hemiptera (He), Hirudinea (Hi), Tricoptera $(\mathrm{T})$, Coleoptera (Co), Planorbidae ( $\mathrm{Pl})$, Cambaridae $(\mathrm{Cr})$, fish eggs(Eg), algae, and gravel

Table 3

Niche width (Levins' standardized index $=B$ ) for seven catostomids sampled from four Iowa rivers, 2009

\begin{tabular}{ll}
\hline Species & $B$ \\
\hline Highfin carpsucker & 0.21 \\
Quillback & 0.53 \\
River carpsucker & 0.41 \\
Golden redhorse & 0.32 \\
Shorthead redhorse & 0.09 \\
Northern hogsucker & 0.19 \\
\hline
\end{tabular}

higher rate for northern hogsucker, golden redhorse, and silver redhorse than for the other species. Although the relationship between gill raker spacing and standard length was dependent on species, northern hogsucker, golden redhorse, and silver redhorse typically had the widest spacing between gill rakers.

\section{Discussion}

This study describes similarities and differences in the trophic ecology of catostomids in Iowa's rivers. In general, Carpiodes spp. had highly diverse diets compared to the other catostomids species. Individuals from all three species not only
Table 4

Morista's food overlap $(C)$ between species combinations for catostomids sampled from four Iowa rivers, 2009

\begin{tabular}{lll}
\hline Species 1 & Species 2 & Morista's C \\
\hline Highfin carpsucker & Quillback & 0.52 \\
& Golden redhorse & 0.07 \\
& Northern hogsucker & 0.06 \\
& River carpsucker & 0.81 \\
& Shorthead redhorse & 0.10 \\
Shorthead redhorse & Silver redhorse & 0.09 \\
& Northern hogsucker & 0.45 \\
& Golden redhorse & 0.42 \\
Golden redhorse & Silver redhorse & 0.67 \\
& River carpsucker & 0.42 \\
& Quillback & 0.38 \\
& Northern hogsucker & 0.39 \\
Quillback & River carpsucker & 0.27 \\
& Silver redhorse & 0.44 \\
River carpsucker & Quillback & 0.25 \\
& Northern hogsucker & 0.22 \\
Northern hogsucker & River carpsucker & 0.66 \\
& Silver redhorse & 0.38 \\
& Silver redhorse & 0.39 \\
& Northern hogsucker & 0.27 \\
& Silver redhorse & 0.48
\end{tabular}

consumed a substantial number and diversity of invertebrates, but they also consumed large amounts of algae, detritus, sand, and gravel. This was reflected in the food niche widths of Carpiodes spp., which were wider than the other catostomid species except golden redhorse. Previous studies on the food habits of Carpiodes spp. have varied in their conclusions. In

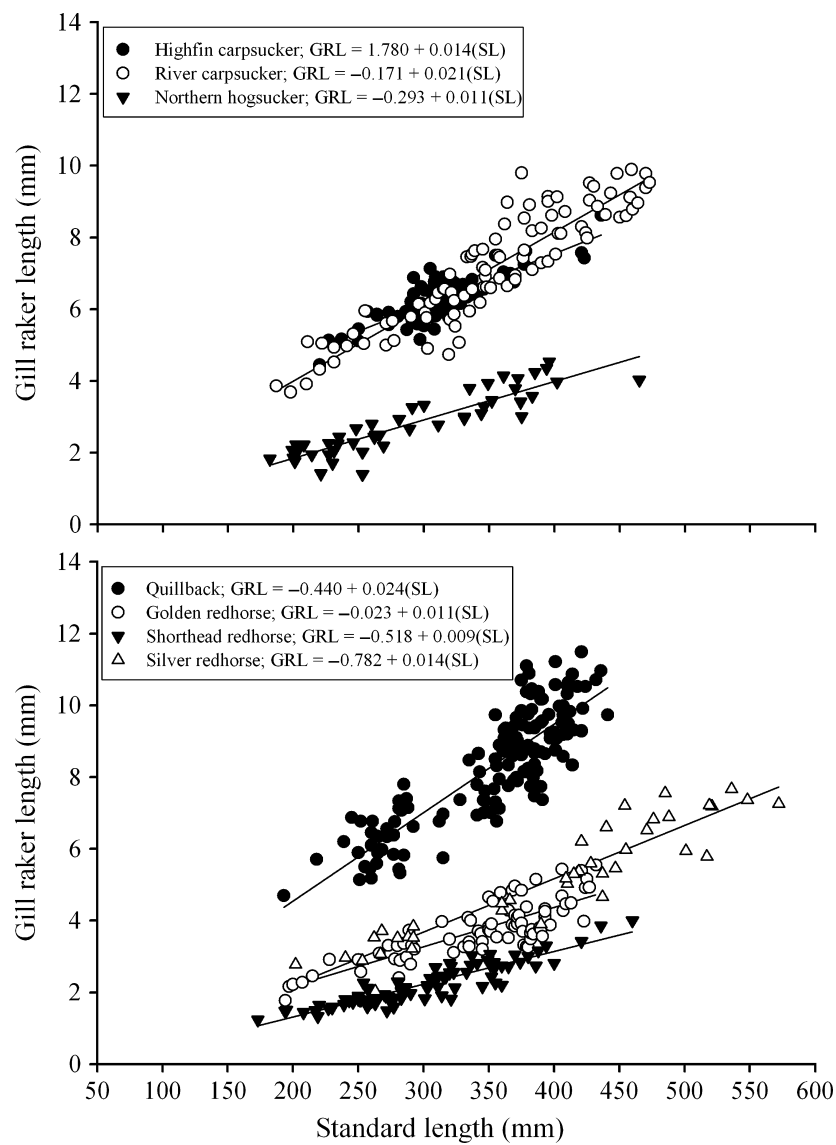

Fig. 2. Gill raker length (GRL) vs standard length (SL) for seven catostomids sampled from four Iowa rivers, 2009 


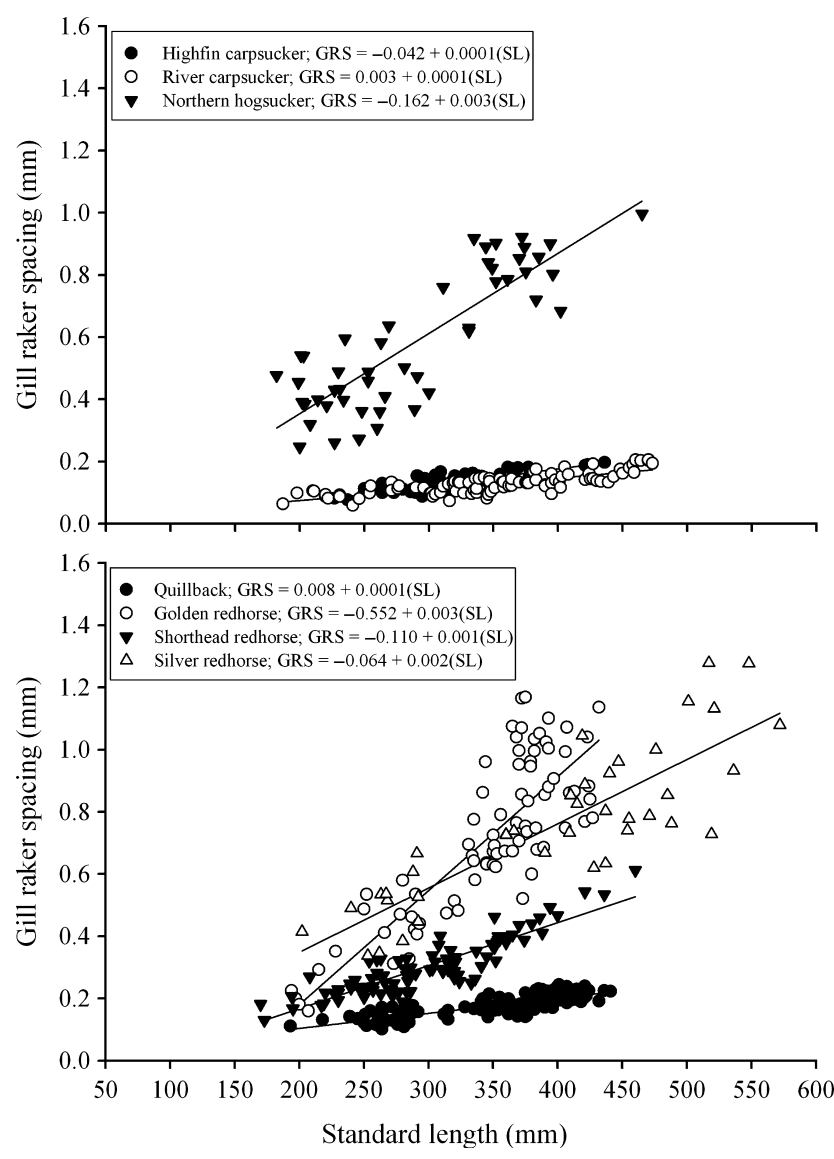

Fig. 3. Gill raker spacing (GRS) vs standard length (SL) for seven catostomids sampled from four Iowa rivers, 2009

the upper Missouri River, river carpsuckers fed primarily on zooplankton (Welker and Scarnecchia, 2003). In contrast, river carpsuckers from the lower Missouri River fed on a variety of prey items, including aquatic insects, oligochaetes, aquatic macrophytes, and mollusks (Brezner, 1958). In the current study, Carpiodes spp. typically had the longest and most closely-spaced gill rakers of the study species. Thus, the diversity of prey items consumed by Carpiodes spp. is likely related to the length and spacing of their gill rakers which allows them to efficiently retain a variety of animal and plant materials (Wright et al., 1983; Gillespie and Fox, 2003). In conjunction with the long, narrowly-spaced gill rakers, the gut morphology of Carpiodes spp. suggests that they are capable of consuming a diversity of prey items. Specifically, the intestine of Carpiodes spp. is different from many other catostomids in that they have a small muscular organ, termed the 'gizzard' in Brezner (1958). The gizzard appears to function as a secondary grinding mechanism. The presence of a gizzard may also explain the large amount of sand and gravel that was often observed in Carpiodes spp. gut contents.

In contrast to Carpiodes spp., golden redhorse, shorthead redhorse, silver redhorse, and northern hogsuckers had gill raker morphology that is likely better adapted to selectively prey on macroinvertebrates. Their gill rakers were more widely spaced and shorter than those of Carpiodes spp. Analyses of gut contents from Moxostoma spp. and northern hogsucker revealed that they rarely contained algae, detritus, silt, sand, or gravel. The increased space between the gill rakers of these species likely allows fine items to be flushed from the buccal cavity, while retaining invertebrates for consumption. For instance, Harlan et al. (1987) reported an observation where a northern hogsucker while feeding on invertebrates also ingested sand and gravel, which was then ejected prior to ingesting prey items. Meyer (1962) found diets of silver redhorse, shorthead redhorse, and golden redhorse to be dominated by insects in the Des Moines River, Iowa. The three most abundant prey taxa were Chironomidae, Ephemeroptera, and Trichoptera. Similarly, shorthead redhorse were reported to primarily consume dipterans, trichopterans, and ephemeropterans in the Mississippi River (Bur, 1976). Northern hogsuckers diets were dominated by ephemeropterans and trichopterans in a Missouri stream (Matheney and Rabeni, 1995). Our study showed similar results where chironomids, ephemeropterans, and trichopterans were generally the most frequently encountered and abundant taxa in the diets of Moxostoma spp. and northern hogsuckers.

Although some differences in diet among catostomids in Iowa rivers were observed, diets could be considered relatively similar among taxa. A likely explanation for the high degree of overlap is that food resources are not limited in Iowa's river systems. When food resources are abundant, coexisting fish species often exhibit high diet overlap (Bettoli et al., 1991). In contrast, when food resources become limiting, species shift to less favored food items and overlap decreases (Werner and Hall, 1976; Schoener, 1982; Bettoli et al., 1991). Werner and Hall (1976) showed that morphological and behavioral differences among bluegill Lepomis macrochirus, pumpkinseed L. gibbosus, and green sunfish L. cyanellus allowed for coexistence. If only one of the three species inhabited a system, a majority of their prey items was strongly associated with aquatic vegetation. However, when all three species were sympatric, each species consumed prey associated with vegetation, but their unique morphological characteristics (e.g. gill rakers) enabled each species to exploit unique resources.

This study provides important information on the trophic ecology of catostomids in rivers of a highly-disturbed landscape. Despite having similar external morphology, differences in gill raker morphology and an ability to use a variety of food resources (e.g. aquatic insects, mollusks, algae, zooplankton) appear to allow a variety of catostomids to coexist in larger river systems. Additional research is needed on the trophic ecology and morphology of catostomids that are declining (e.g. black redhorse) to better understand their habitat requirements and the potential influence of species interactions. In addition, future work should examine growth and diets of catostomids in different assemblages to help elucidate the influence of resource partitioning on population dynamics and fish assemblage structure.

\section{Acknowledgements}

We thank L. Brown, N. Hogberg and M. Mork for their assistance in the field and laboratory. This project was supported, in part, by Iowa State University-Department of Natural Resource Ecology and Management, the Iowa Department of Natural Resources (IDNR) through Grant No. 07-04HA-18, and the Idaho Cooperative Fish and Wildlife Research Unit. The Unit is jointly sponsored by the University of Idaho, U.S. Geological Survey, Idaho Department of Fish and Game, and Wildlife Management Institute. The use of trade, firm, or product names is for descriptive purposes only and does not imply endorsement by the U.S. Government or IDNR. 


\section{References}

Amundsen, P. A.; Gabler, H. M.; Staldvik, F. J., 1996: A new approach to graphical analysis of feeding strategy from stomach contents data-modification of the Costello (1990) method. J. Fish Biol. 48, 607-614.

Angradi, T. R.; Griffith, J. S., 1990: Diel feeding chronology and the diet selection of rainbow trout (Oncorhynchus mykiss) in the Henry's Fork of the Snake River, Idaho. Can. J. Fish. Aquat. Sci. 47, 199-209.

Barton, M., 2007: Bond's biology of fishes, 3rd edn. Thompson Brooks / Cole, Belmont, CA.

Bertrand, K. N.; Gido, K. B., 2007: Effects of the herbivorous minnow, southern redbelly dace (Phoxinus erythrogaster), on stream productivity and ecosystem structure. Oecologia 151, 69-81.

Bettoli, P. W.; Morris, J. E.; Noble, R. L., 1991: Changes in the abundance of two atherinid species after aquatic vegetation removal. Trans. Am. Fish. Soc. 120, 90-97.

Bowen, S. H., 1996: Quantitative description of diet. In: Fisheries techniques, 2nd edn. B. R. Murphy and D. W. Willis (Eds). American Fisheries Society, Bethesda, MD, pp. 513-532.

Brezner, J., 1958: Food habitats of the northern river carpsucker in Missouri. Progr. Fish-Cult. 20, 170-173.

Bur, M. T., 1976: Age, growth and food habits of Catostomidae in Pool 8 of the upper Mississippi River. M. Sc. Thesis, University of Wisconsin, La Crosse, WI

Burkhardt, R. W.; Gutreuter, S., 1995: Improving electrofishing consistency by standardizing power. N. Am. J. Fish. Manage. 15, 375-381.

Chipps, S. R.; Garvey, J. E., 2007: Assessment of diets and feeding pattern. In: Analysis and interpretation of freshwater fisheries data. C. S. Guy and M. L. Brown (Eds). American Fisheries Society, Bethesda, MD, pp. 473-514.

Cooke, S. J.; Bunt, C. M.; Hamilton, S. J.; Jennings, C. A.; Pearson, M. P.; Cooperman, M. S.; Markle, D. F., 2005: Threats, conservation strategies, and prognosis for suckers (Catostomidae) in North America: insights from regional case studies of a diverse family of non-game fishes. Biol. Conserv. 121, 317-331.

Cooper, C. M., 1987: Benthos in Bear Creek, Mississippi: effects of habitat variation and agricultural sediments. J. Freshw. Ecol. 4, 101-113.

Ehlinger, T. J.; Wilson, D. S., 1988: A complex foraging polymorphism in bluegill sunfish. Proc. Nat. Acad. Sci. 85, 1878-1882.

Gillespie, G. J.; Fox, M. G., 2003: Morphological and life-history differentiation between littoral and pelagic forms of pumpkinseed J. Fish Biol. 62, 1099-1115.

Gray, E. V.; Boltz, J. M.; Kellogg, K. A.; Stauffer, J. R., Jr, 1997 Food resource partitioning by nine sympatric darter species. Trans. Am. Fish. Soc. 126, 822-840.

Harlan, J. R.; Speaker, E. B.; Mayhew, J., 1987: Iowa fish and fishing. Iowa Conservation Commission, Des Moines.

Holopainen, A. L.; Huttunen, P., 1992: Effects of forest clearcutting and soil disturbance on the biology of small forest brooks. Hydrobiologia 244, 457-464.

Ingram, T.; Shurin, J. B., 2009: Trait-based assembly and phylogenetic structure in northeast Pacific rockfish assemblages. Ecology $\mathbf{9 0}$ 2444-2453.

Jelks, H. L.; Walsh, S. J.; Contreras-Balderas, S.; Diaz-Pardo, E.; Hendrickson, D. A.; Lyons, J.; Mandrak, N. E.; McCormick, F.; Nelson, J. S.; Platania, S. P.; Porter, B. A.; Renaud, C. B.; Schmitter-Soto, J. J.; Taylor, E. B.; Warren, M. L., Jr, 2008 Conservation status of imperiled North American freshwater and diadromous fishes. Fisheries 33(8), 372-407.

Karr, J. R.; Toth, L. A.; Dudley, D. R., 1985: Fish communities of midwestern rivers: a history of degradation. BioSci. 35, 90-95.

Litvan, M. E.; Stewart, T. W.; Pierce, C. L.; Larson, C. J., 2007: Effects of grade control structures on the macroinvertebrate assemblage of an agriculturally impacted stream. River Res. Appl. 24, 218 233
Marshall, S.; Elliott, M., 1997: A comparison of univariate and multivariate numerical and graphical techniques for determining inter- and intraspecific feeding relationships in estuarine fish. J. Fish Biol. 51, 526-545.

Matheney, P. M.; Rabeni, C. F., 1995: Patterns of movement and habitat use by northern hogsuckers in an Ozark stream. Trans. Am. Fish. Soc. 124, 886-987.

McNeely, D. L., 1987: Niche relations within an Ozark stream cyprinid assemblage. Environ. Biol. Fishes 18, 195-208.

Meyer, W. H., 1962: Life history of three species of redhorse (Moxostoma) in the Des Moines River, Iowa. Trans. Am. Fish. Soc. 91, 412-419.

Miller, J. L.; Hamon, T.; Jones, T.; West, F., 2007: Kokanee exploit large prey in the absence of limnetic predators. In: Sockeye salmon evolution, ecology, and management. C. A. Woody (Ed.). American Fisheries Society, Bethesda, MD, pp. 73-83.

Morgan, R. P., II; Rasin, J., Jr; Noe, L. A., 1983: Sediment effects on eggs and larvae of striped bass and white perch. Trans. Am. Fish. Soc. 112, 220-224.

Natural Resources Conservation Service (NRCS), 2000: Natural resources inventory. 1997 Summary Report. U.S Department of Agriculture, Ames, Iowa.

Neebling, T. E.; Quist, M. C., 2010: Fish assemblages in Iowa's nonwadeable rivers: relationships with habitat and sampling methods. Fish. Manage. Ecol. 17, 369-385.

Nelson, G. J., 1967: Epibranchial organs in lower teleostean fishes. J. Zool. 153, 71-89.

O'Brien, W. J.; Luecke, C., 1983: A new estimate of zooplankton retention by gill-rakers and its ecological significance. Trans. Am. Fish. Soc. 112, 638-646.

SAS Institute, 2008: The SAS system for windows, version 9.2, SAS Institute, Cary, NC.

Schoener, T. W., 1982: The controversy over interspecific competition. Am. Sci. 70, 586-595.

Smith, E. P.; Zaret, T. M., 1982: Bias in estimating niche overlap. Ecology 63, 1248-1253.

Tanaka, H.; Aoki, I.; Ohshimo, S., 2006: Feeding habits and gill raker morphology of three planktivorous pelagic fish species off the coast of northern and western Kyushu in summer. J. Fish Biol. 68, 1041-1061.

Walser, C. A.; Bart, H. L., Jr, 1999: Influence of agriculture on in-stream habitat and fish community structure in Piedmont watersheds of the Chattahoochee River System. Ecol. Freshw. Fish. 8, 237-246.

Welker, T. L.; Scarnecchia, D. L., 2003: Differences in species composition and feeding ecology of catostomid fishes in two distinct segments of the Missouri River, North Dakota, U.S.A. Environ. Biol. Fishes 68, 129-141.

Werner, E. E.; Hall, D. J., 1976: Niche shifts in sunfishes: experimental evidence and significance. Science 191, 404-406.

Wood, C. C., 2007: Sockeye salmon ecotypes: origin, vulnerability to human impacts, and conservation value. In: Sockeye salmon evolution, ecology, and management. C. A. Woody (Ed.) American Fisheries Society, Bethesda, MD, pp. 1-4.

Wright, D. I.; O'Brien, W. J.; Luecke, C., 1983: A new estimate of zooplankton retention by gill rakers and its ecological significance. Trans. Am. Fish. Soc. 112, 638-646.

Zaret, T. M.; Rand, A. S., 1971: Competition in tropical stream fishes: support for the competitive exclusion principle. Ecology 52, 336342

Zohrer, J. J., 2006: Iowa comprehensive wildlife conservation plan Iowa Department of Natural Resources, Des Moines.

Author's address: Michael C. Quist, U.S. Geological Survey, Idaho Cooperative Fish and Wildlife Research Unit, Department of Fish and Wildlife Resources, Box 441141, University of Idaho, Moscow, ID 83844 USA.

E-mail: mcquist@uidaho.edu 